\title{
再生可能な植物油脂ベースポリマーの開発 Development of Sustainable Plant Oil-Based Polymers
}

\author{
宇山浩* \\ Hiroshi UYAMA
}

\section{1.はじめに}

平成 14 年暮れに日本政府の総合戦略「バイオマスニッ ポン」が発表され, バイオマスの利活用による持続的に発 展可能な社会の実現がうたわ机ている。この戦略は, バイ オマスの有効利用に基づく地球温暖化防止や循環型社会形 成の達成, 更には日本独自のバイオマス利用法の開発によ る戦略的産業の育成を目指すものである。また, 地球規模 での環境保護の観点から，バイオマス原料は日本のみなら ず，世界中から安価かつ豊富な資源の積極的な利用が求め られている。

プラスチックは化学工業の主幹産業であり, 我々の日常 生活に欠かすことのできない材料である。現在のプラスチッ クの大部分は石油から作られているが, 脱石油, 地球環境 保護の観点から好ましくない。そこで, 近年, 地球温暖化 を抑制し，地球環境に優しいプラスチック材料として，天 然物を中心之する再生可能資源を出発原料之する“バイオ ベースポリマー”が注目されてきた。バイオベースポリマー は自然界の物質循環の組み込まれるものであるため, 二酸 化炭素の增加につながらない(“カーボンニュートラル”)。 そのため, バイオベースポリマーは循環型社会構築に大き く寄与する未来型材料として，その実用化が急務である。 バイオベースポリマーの代表例として, 多糖系材料とポ リ乳酸が挙げられる。前者は主鎖に糖骨格を有し, 親水性 を示すため, 工業用途が限定されている。そこで既存のプ ラスチックに近い性質を示すポリ乳酸に関する研究が活発 に行われ，ポリプロピレンをはじめとする幾つかの石油由 来のプラスチックの代替を目指した用途開発が積極的に検 討されてきた。しかし，ポリ乳酸は石油由来のプラスチッ クの 2 倍以上の価格であり, しかも, 現時点では物性・機

\footnotetext{
*大阪大学 大学院工学研究科

大阪府吹田市山田丘 2-1 于 565-0871

Graduate School of Engineering, Osaka University

2-1 Yamadaoka, Suita, 565-0871, Japan
}

能む石油由来のプラスチックの同等以下である場合が多い。 そのため，実用化例の多くが環境対応を目指す企業の限定 された用途や官による助成事業（愛知万博等）に留まって いる。

本稿では第三のバイオベースポリマーとしての油脂ベー ス高分子の実用材料としての潜在性を述べる。植物油脂は 全世界で年間約一億トン生産されており, 汎用高分子材料 の出発物質として高い潜在性を有している ${ }^{1 \sim 3)}$ 。安価な大 豆油等のトリグリセリドの不飽和基の反応を利用したアル キド樹脂が工業的に塗料として用いられている。顔料分散 性や塗装性に優れ，仕上がりの美観や耐久性も良い点に特 徵がある。最近では大豆油の新聞インキとしての利用が社 会的に注目されている。また, 油脂から誘導化したポリオー ルを用いたポリウレタンむ開発されている。ここでは筆者 らが展開してきたエポキシ化植物油脂を出発原料とする油 脂複合材料に関する研究を中心に紹介する。

\section{2. 植物油脂ークレイナノコンポジット}

ポリマー系ナノコンポジットの重要なナノフィラーとし てクレイ（粘土）が挙げられる ${ }^{4 \sim 6)}$ 。クレイは陶器や磁器 の原料であり，力オリナイトと呼ばれる粘土鉣物が主成分 である。ナノフィラーとしてはモンモリロナイトがよく用 いられる。モンモリロナイトは火山灰中のガラス成分が分 解して生成したすので, 層状ケイ酸塩鉱物の一種であるス

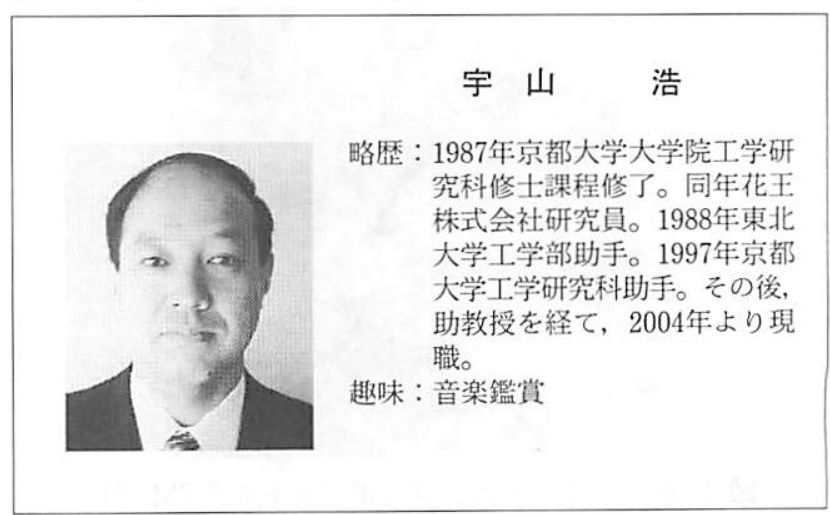


メクタイトに分類される。モンモリロナイトはケイ酸四面 体層ーアルミナ八面体層一ケイ酸四面体層の三層が積み重 なったものであり, 厚さ約 $1 \mathrm{~nm}$, 広がり $0.1 \sim 1 \mu \mathrm{m}$ とい う極めて薄い板状構造をとる。このケイ酸塩層の間にナト リウムイオンがあり, アミン化合物とのイオン交換により, 容易に有機变性クレイが得られる。有機変性により有機物 （特に疎水性化合物）との親和性が向上するため, ポリマー 系ナノコンポジットでは有機变性クレイがよく用いられる。

植物油脂ークレイナノコンポジットは有機成分として主 にエポキシ化大豆油（ESO）を用い, 有機修飾クレイの 存在下, 少量のカチオン性熱潜在性開始剤を添加して熱処 理を行うことにより合成された（図 1） ${ }^{7,8)}$ 。本ナノコンポ ジットの有機, 無機原料は共に安価な天然素材である。才 クタデシルアミン塩酸塩で有機化したモンモリロナイト （有機修飾クレイ，C18-Mont）を用いたところ，柔軟性 に富む ESOークレイナノコンポジットが得られた。 TEM 観察からケイ酸塩層は数層単位でスタックしているものの, ポリマー中に均一に分散していることがわかった（図 2)。 また, 広角 X 線测定から, エポキシ化大豆油のインター カレーションにより有機変性クレイの層間距離が増大し, クレイ含量が少ない場合には良好な分散性が推察された。 動的粘弾性測定からむナノコンポジットの均一分散が確認

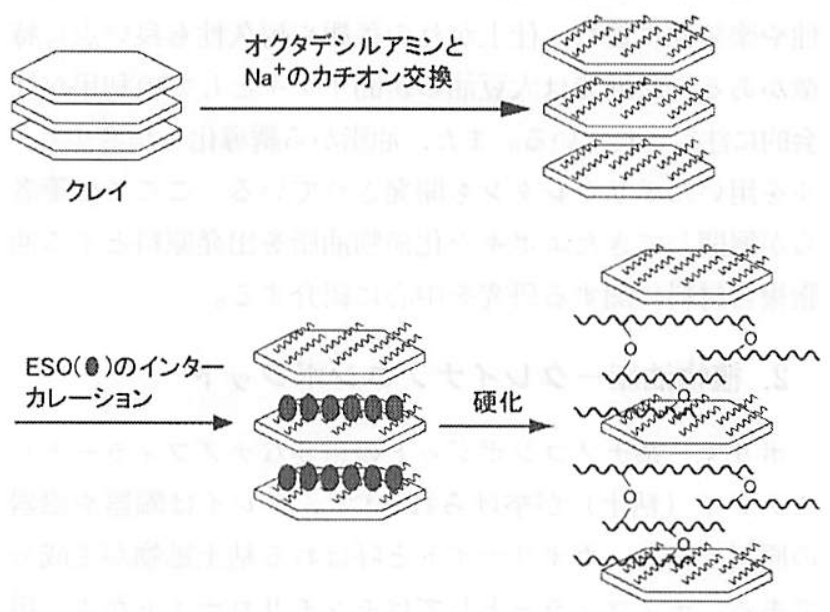

図 1 植物油脂ークレイナノコンポジットの合成

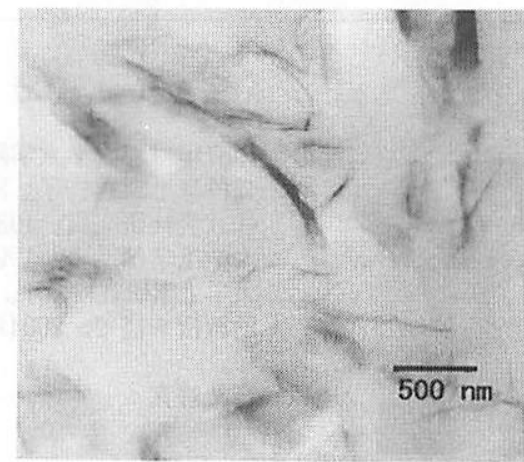

図 $2 \mathrm{ESO}$-クレイナノコンポジットの TEM 写真
され, クレイ含量が多いほど貯蔵弾性率が增大したことか ら，ポリマーマトリックス中でのケイ酸塩層による補強効 果が示された。

油脂種の動的粘弾性挙動に対する影響が調べられた。全 温度範囲でエポキシ化亜麻仁油を用いて作製したコンポジッ トの貯蔵弾性率が大豆油からのコンポジットより大きく, エポキシ化亜麻仁油 (ELO) -クレイコンポジットが優れ た物性を有することがわかった。この違いは, 亜麻仁油の 不飽和度が大豆油より高いために（亜麻仁油の不飽和度： 7〜8, 大豆油の不飽和度 : 5〜6), 有機ポリマーマトリッ クスの架橋密度が増大したことに起因すると考えられる。 力学物性に関しては, クレイを多く添加するほど初期弾性 率と破断応力が増大し, 破断歪みはほぼ変化しなかった。

本ナノコンポジットを空気雾囲気下, $900^{\circ} \mathrm{C}$ で熱処理す ることにより, 多孔性セラミックが得られた。これは熱処 理によって有機成分が分解し, マトリックス中に分散して いたシリケート層が数層単位で凝集しながら残ったためで あると考えられる。ポリマーークレイナノコンポジットで はポリマー単独よりガスバリア性が向上することが知られ ている。本ナノコンポジットの水蒸気バリア性が評価され, ESO 単独硬化物のフィルムよりもナノコンポジットフィ ルムの方が高いバリア性を示すことがわかった。これは, ポリマーマトリックス中にナノオーダーで分散したシリケー 卜層を水分子が过回して通るためと考えられる。

\section{3. 植物油脂ーシリカナノコンポジット}

ゾルーゲル法を利用したナノコンポジットも活発に研究

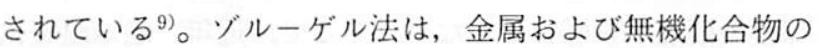
溶液をゲルとして固化し，このゲルの加熱により酸化物の 固体を作製する方法であり，基本的には無機ガラスを比較 的低温で作製する方法として発展してきた。シリカ, アル ミナ, チタニア, ジルコニアなどの金属のアルコキシドが 主に用いられる。

有機成分と無機成分を共有結合で介させることで無機成 分をナノレベルで分散させる手法が提案された ${ }^{10)}$ 。有機 成分として主に ESO を用い，エポキシ基含有シランカッ プリング剤（GPTMS）存在下, 少量のカチオン性熱潜在 性開始剤を添加して熱処理を行うことにより，油脂ーシリ カナノコンポジットが合成された（図 3)。本反応では GPTMS と ESO のエポキシ基が共重合し，さらに GPTMS のアルコキシシラン部位の重縮合により無機成分が凝集し たナノドメインを形成すると考えられる。また, TEM 観 察や EPMA によるシリコン原子のマッピングにより無機 成分が良好に分散していることがわかった。

ナノコンポジットの塗膜物性が調べられた。ESOの単 独硬化では十分な硬度を有する塗膜は得られなかったが (鉛筆硬度 $2 B$ ), GPTMS を $5 \%$ 添加するだけで鉛筆硬度 


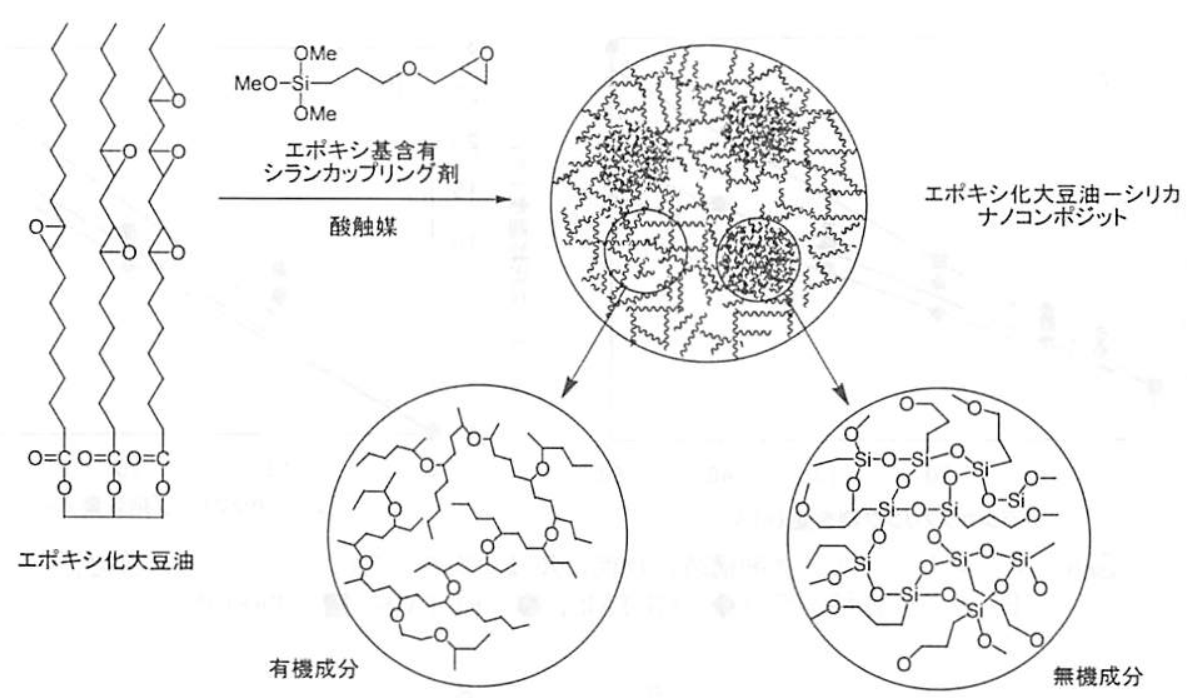

図 3 植物油脂ーシリカナノコンポジットの合成

(A)

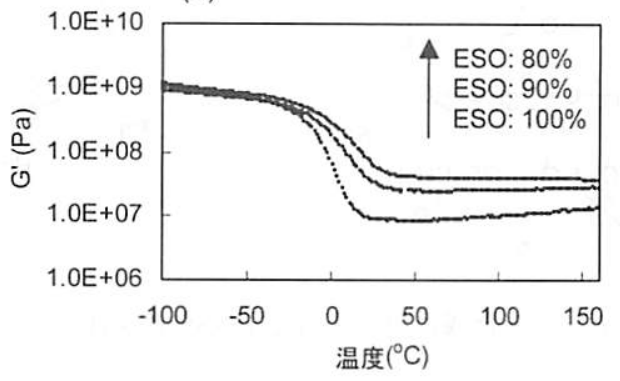

(B)

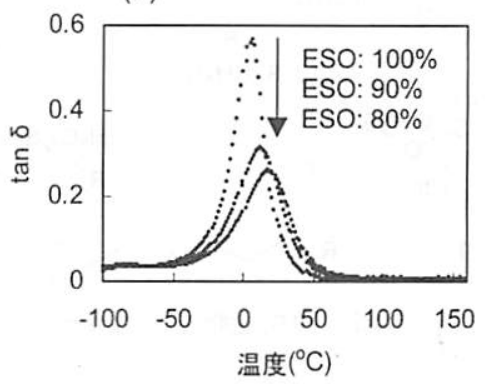

図 $4 \mathrm{ESO}$-シリカナノコンポジットの動的粘弾性挙動：(A) 貯蔵弾性率, (B) $\tan \delta$

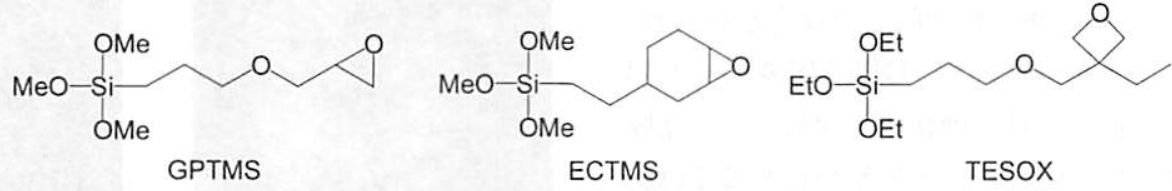

図 5 植物油脂ーシリカナノコンポジット合成に用いられるシランカップリング剂

はHとなった。また, GPTMSの添加量に伴い, ユニバー サル硬度とヤング率が実用レベルまで向上した。一方, GPTMS を添加しても塗膜の弾力性は保持された。更にい ずれの場合も透明性と光沢性の優れた塗膜が得られた。 ELO を用いた場合にも透明な塗膜が得られ，GPTMSの 添加により塗膜物性の向上が見られた。ELOから得られ たナノコンポジットの硬度とヤング率は大豆油由来のナノ コンポジットより大幅に増大したが,これは亜麻仁油の不 飽和度が大豆油より高いためと思われる。

動的粘弾性評価では油脂単独硬化物と比較して ESOシリカナノコンポジットの高温部での貯蔵弾性率が上昇し ており, シランカップリング㶡の添加による補強効果が示 された（図 4)。また, GPTMSの添加量に伴いガラス転 移温度の上昇が見られた。ELOを用いた場合, ナノコン ポジットのガラス転移温度は上昇したが, 油脂種による補 強効果の違いは見られなかった。また, 初期弾性率と破断
応力も GPTMS の添加に伴い, 大幅に向上した。尚, GPTMS の代わりにテトラエトキシシランを用いたところ, このような物性向上は見られなかった。これらの結果はナ ノコンポジットの機能向上に有機ポリマーと無機ドメイン 間の共有結合形成が重要な役割を果たすことを示している。 また, 活性污泥中において BOD 法により生分解性が評価 された。分解は徐々に進行し，50日後に50\%以上が分解 し, 本ナノコンポジットの高い生分解性が明らかとなった。 シランカップリング剤構造の影響が調べられた（図 5) ${ }^{11}$ 。 シクロヘキセンエポキシ基を有するシランカップリング剤 を用いた場合に硬化膜硬度，ガラス転移温度ともに最も高 かった（図6）。また, 全てのシランカップリング斉で添 加量による物性の直線的相関が見られた。

近年, 籠型シルセスキオキサン（POSS）が機能材料の 前駆体として注目されており, 籠型構造に起因する特徴あ る物性が POSS を含むハイブリッドで見出されている ${ }^{12)}$ 。 

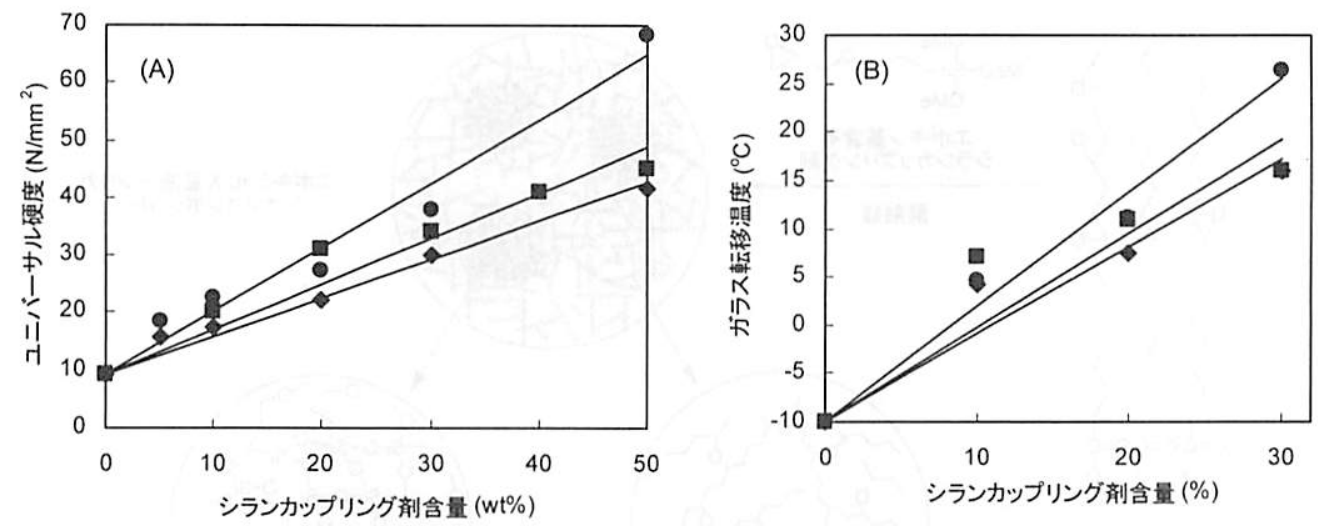

図 6 シランカップリング剂構造の物性に及ぼす影響：(A) ユニバーサル硬度,

(B) ガラス転移温度 $($ : GPTMS, ○ : ECTMS, ロ : TESOX $)$

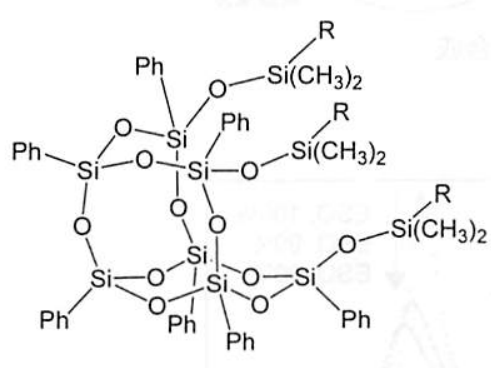

1

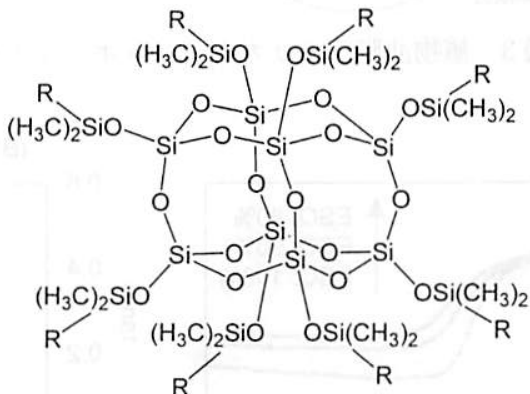

2

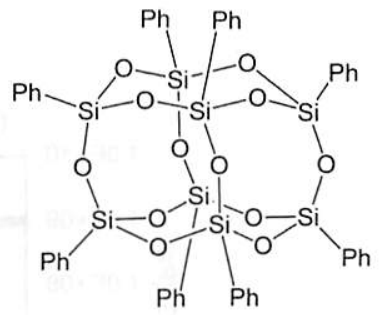

3

図 7 植物油脂ーシリカナノコンポジット合成に用いられる POSS 誘導体

最近, POSS を利用することで無機成分のナノ構造を制御 したナノコンポジットが開発された。エポキシ基含有の POSS（図 7）を用い，エポキシ化油脂との反応が行われ， 透明なナノコンポジットが得られた。GPTMS を用いた場 合と同様, エポキシ化油脂単独の硬化物と比較して, 塗膜 物性の向上が見られた。エポキシ基を 8 個有する POSS （2）を用いて作製したナノコンポジットのほうがエポキシ 基を 3 個有するPOSS（1）よりも，鉛筆硬度，ユニバー サル硬度，ヤング率の向上が顕著であった。また，ELO を用いた場合，ESO から合成したナノコンポジットより 鉛筆硬度, ユニバーサル硬度，ヤング率に優れていた。こ れは ELO のほうが油脂中のエポキシ基数が多いためと思 われる。一方, We/Wtot は ELO を用いた場合に大幅に 低下し，柔軟性については ESO を基盤とするナノコンポ ジットが優れていた。

エポキシ基含有 POSS の添加による油脂硬化物の補強 硬化が動的粘弾性測定から評価された。POSS の添加によ りガラス転移温度が上昇し，ガラス転移温度以上での貯蔵 弾性率が大幅に向上し, 初期弾性率, 破断応力の向上も見 られた。一方，エポキシ基を持たないオクタフェニル POSS 誘導体（3）を添加して得られたコンポジットの物 性はエポキシ化油脂単独の硬化物とほぼ同じであった。こ れらの結果から，エポキシ基を有する POSS 老用いて有 機成分と無機成分間に共有結合を介することにより物性が

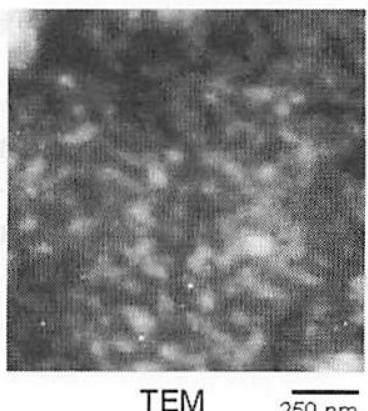

TEM $\quad \overline{50 \mathrm{~nm}}$

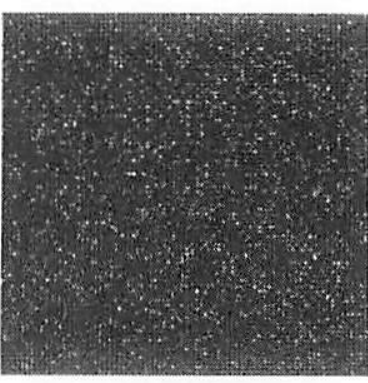

EPMA $\overline{4 \mu \mathrm{m}}$
図 8 ESO-POSSナノコンポジットの TEM, EPMA 写真

向上したことがわかった。

POSS 成分のマトリックスポリマー中における分散性が TEM と EPMA を用いて調べられた。TEM 測定では POSS 同士の重合による数十 $\mathrm{nm}$ の無機成分が観測され, EPMA では試料中にシリカ成分が均一に分散している ことがわかった（図 8)。これらの結果はエポキシ基含有 POSS を用いた場合に無機成分が有機ポリマーマトリック スにナノレベルで分散していることが示すあのである。更 にこの無機成分の良好な分散性が物性の向上にむ寸びつい たものと考えられる。

\section{4. 植物油脂一生分解性ポリマー複合材料}

代表的な生分解性ポリエステルであるポリ（カプロラク トン)（PCL）は融点 $60^{\circ} \mathrm{C}$ の結晶性ポリマーであり ${ }^{13)}$, 耐 


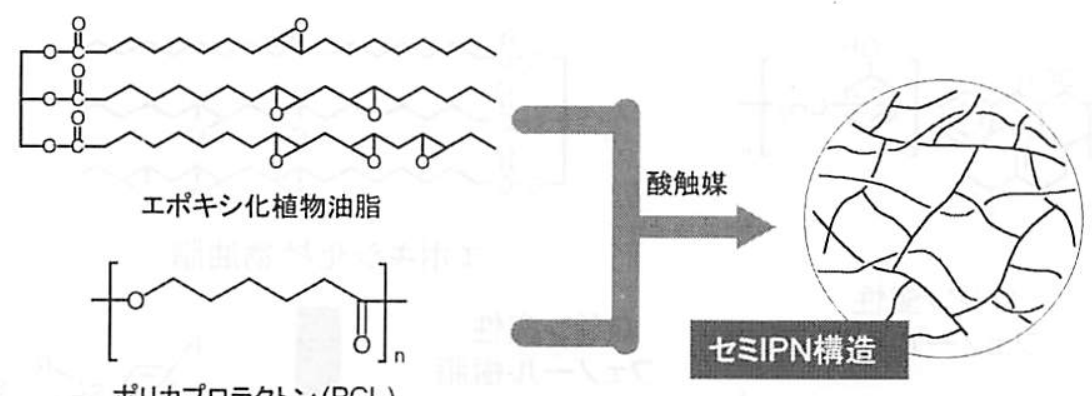

ポリカプロラクトン(PCL)

図 9 七ミ IPN 型植物油脂-PCL 複合材料の合成
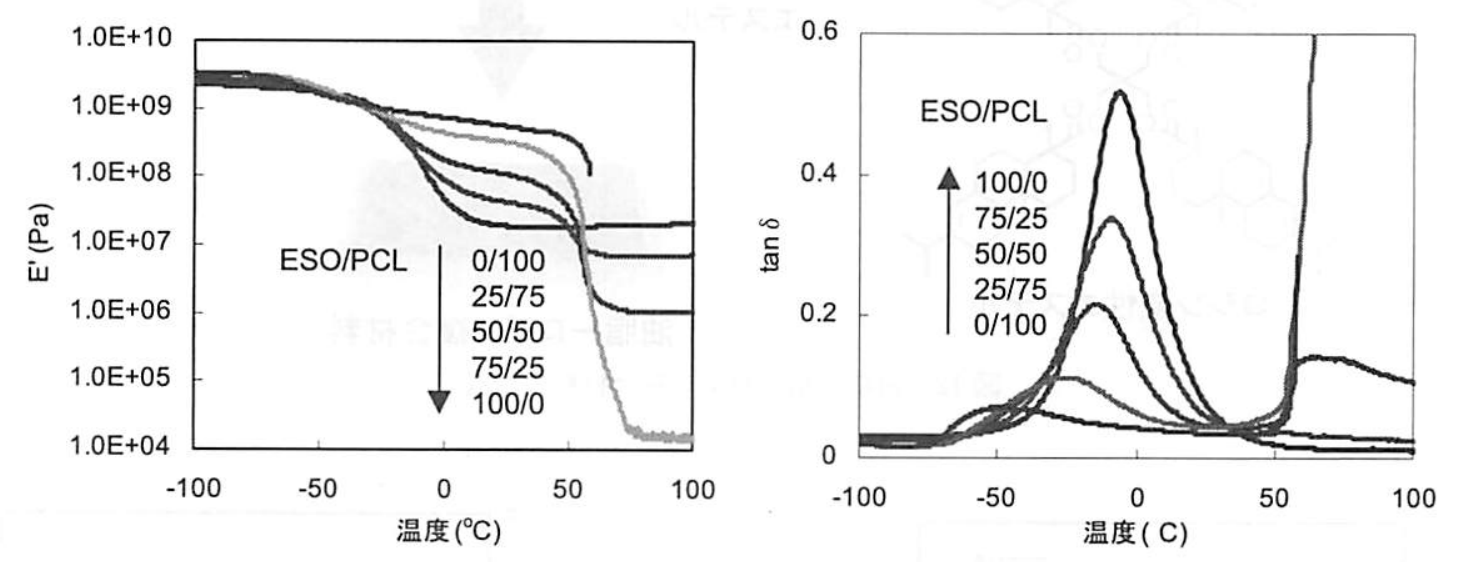

図 10 ESO-PCL 複合材料の動的粘弾性挙動

熱性の低さが問題視されている。ESO 硬化ポリマーネッ トワーク中にナノレベルで PCL を分散化させる手法が開 発された。ESO に PCL を溶解させ, 触媒を加えて加熱す るという簡便な方法により，七ミ IPN 型の ESO-PCL 複 合材料が合成された（図 9)。

得られたセミ IPN 化物の動的粘弾性測定が行われ, PCL の添加量が増加するにつれて常温領域の貯蔵弾性率 (E') が増加し, 高温領域では減少した（図 10）。これは PCL の融点が $60^{\circ} \mathrm{C}$ であるためと思われる。また, 眝蔵弾性率 と損失弾性率の比で表される $\tan \delta$ のピークは低温側に シフトした。これは PCLのガラス転移温度 $\left(-60^{\circ} \mathrm{C}\right)$ が エポキシ化大豆油硬化物のガラス転移温度より低いためで ある。更にガラス転位を示すピークが単分散であったこと からエポキシ化大豆油硬化物と PCL は良好に分散してい ることが示唆された。

エポキシ化油脂の単独硬化では架橋密度が高いために十 分な延性は得られない。しかし, PCL を添加することに よって架橋密度か減少し, 歪みやすくなるために延性の向 上が期待される。このセミIPN 化物の一軸伸長試験では, PCL の添加量が增加するにつれて, 破断強度, 初期弾性 率及び破断歪みが大幅に增加した（図 11）。これらの結果 から, 複合化により油脂硬化ポリマーの硬く脆い欠点が解 消し, 七ミIPN 化により油脂硬化䟡一の力学特性が 大幅に向上すると同時に，七ミIPN 化により耐熱性に劣 る PCL の融点以上での使用が可能となり, 耐熱性が著し

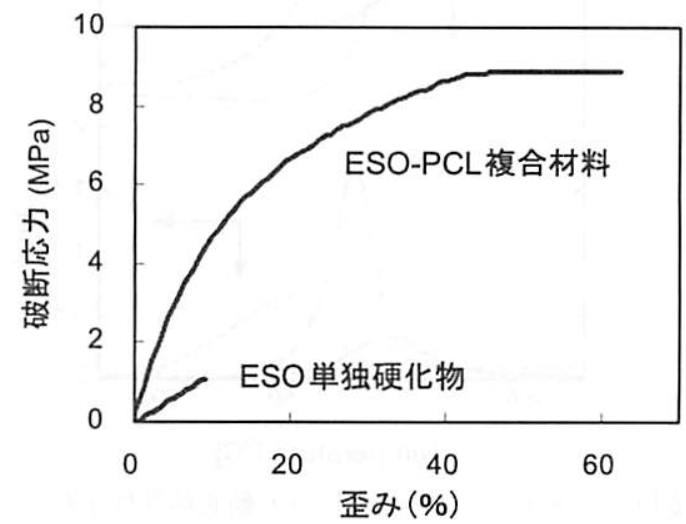

図 11 ESO-PCL 複合材料の歪み一破断応力曲線

く改善されることがわかった。

\section{5. 植物油脂ーロジン誘導体複合材料}

天然物であるロジン（松脂）の各種誘導体は比較的安価 であり, 接着・粘着力を付与できることから, 工業的に幅 広く用いられる樹脂改質剤である。ロジン系添加郕（ロジ ンペンタエリトリトールエステルおよびロジン変性フェノー ル樹脂）を導入することにより，機械的特性に優れる新し い複合材料が開発された。これらのロジン誘導体を含む ESO に力チオン熱潜在性開始剤を添加し加熱処理を行い, 透明な樹脂硬化物が得られた（図 12）。

これらの複合材料の動的粘弾性測定では（図 13), ESOロジンペンタエリトリトールエステル系硬化物は ESO 単 


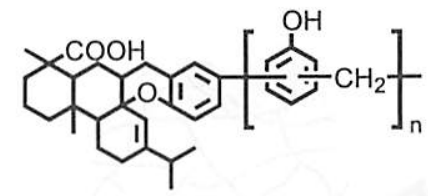

ロジン変性 フェノール樹脂

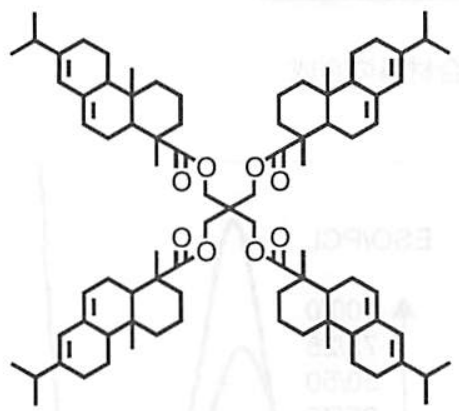

ロジン変性エステル

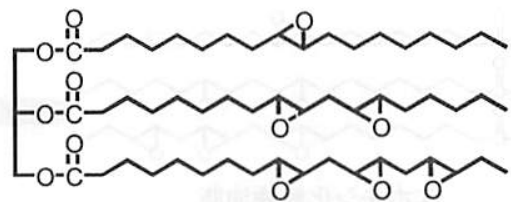

エポキシ化植物油脂

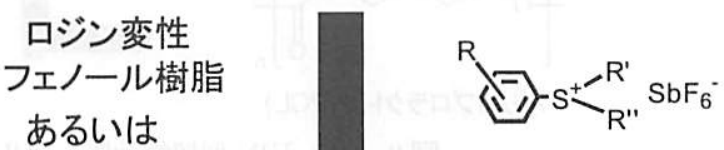

熱潜在性開始剂

ロジン変性

エステル

図 12 植物油脂一ロジン複合材料の合成

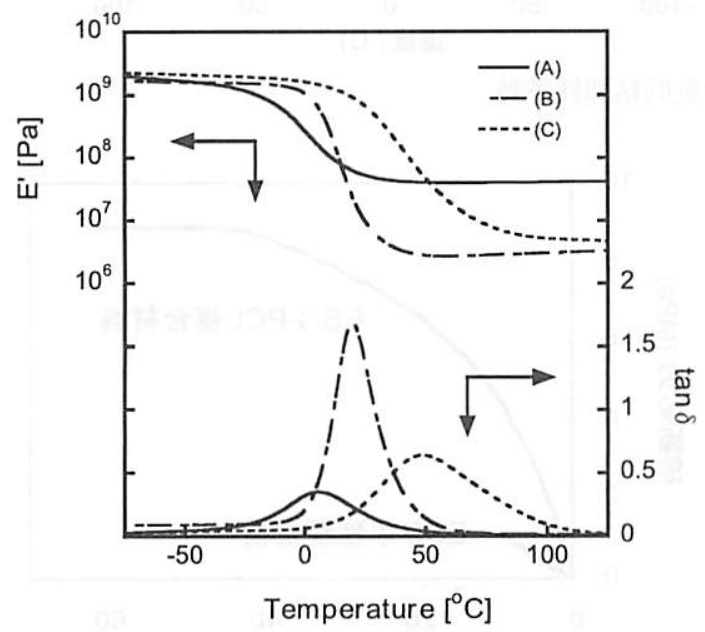

図 $13 \mathrm{ESO}$-ロジン複合材料の動的粘弾性挙動：

(A) ESO 単独硬化物, (B) ロジン変性エス

テル添加，(C) ロジン変性フェノール樹脂添加

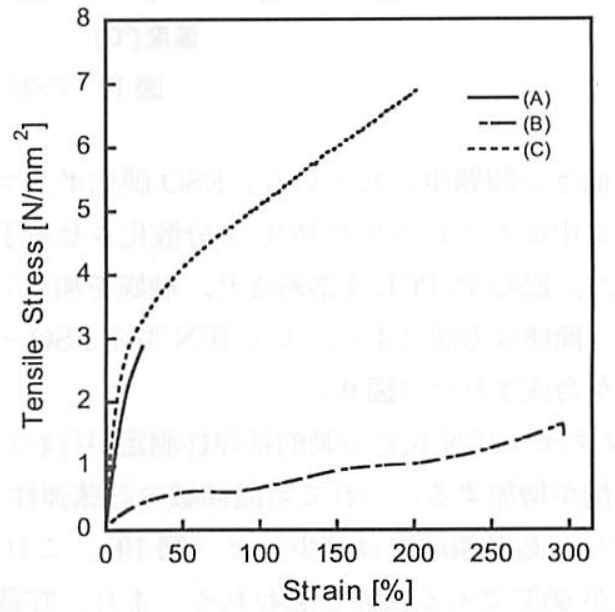

図 $14 \mathrm{ESO}$-ロジン複合材料の力学特性：(A) ESO 単独 硬化物,（B）ロジン変性エステル添加，（C）ロジン 変性フェノール樹脂添加

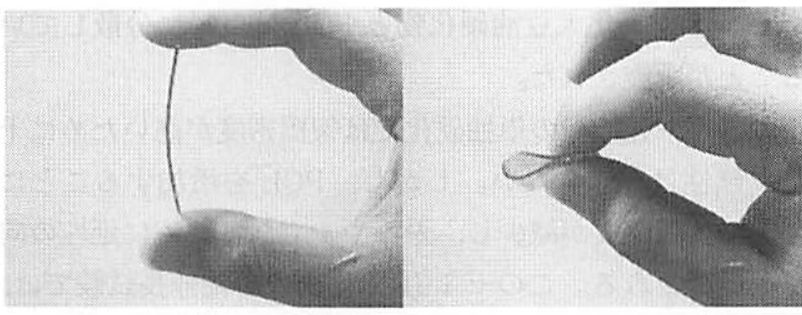

図 $15 \mathrm{ESO}$-ロジン変性エステル複合材料の柔軟性

高温側へシフトし，ガラス転移温度がより高いことがわかっ た。一軸伸張試験から，ロジン変性フェノール添加系は口 ジンペンタェリトリトールエステル添加系と同様に, ESO 単独硬化物之比べて破断ひずみが向上し，機械的特性に優 より柔軟であることがわかった（図 15）。また, $\tan \delta$ カ ブはロジンペンタェリトリトールエステル添加系に比べて
独硬化物と比較してゴム領域における貯蔵弾性率が小さく, より柔軟であることがわかった。 $\tan \delta$ カブは高温側へ シフトし，ガラス転移温度がより高いことが明らかとなっ さく柔軟であるとともに，破断ひずみが約 10 倍向上し， 㙨械的特性に優れることが明らかとなった（図 14）。

$\mathrm{ESO}$-ロジン変性フェノール樹脂系硬化物は, ロジン ペンタエリトリトールエステル添加系と同様に, ESO 単 独硬化物と比べてゴム領域における眝蔵弾性率が小さく,

\section{油脂ーロジン複合材料}


れるとともに，ロジンペンタエリトリトールエステル添加 系とは異なって, 弾性率および引張強度が ESO 単独硬化 物に比べて大きくなることが明らかとなった。

\section{6. おわりに}

植物油脂を利用する高分子材料，複合材料は古くから研 究されてきたが，実用的物性が得られにくいことから，実 用化例は多くない。しかし，持続的社会構築に向けた再生 可能資源からの材料開発が社会的に望まれており ${ }^{14 \sim 16)}$, 油脂を高分子材料の原料として見直すべき時期が来ている と考えている。油脂の単独重合体に足りない物性・機能を 有機あるいは無機物とのナノレベルでの複合化により高性 能化・高機能化が可能であろう。また, 油脂の組成を遺伝 子レベルで改質する技術を利用することにより，高分子原 料用に Tailor-Made な油脂の開発も可能である。今後, 幅広い分野の研究者が結集して油脂を基盤とするバイオベー ス材料の開発が益々発展することを期待している。

\section{文献}

1) D. L. Kaplan, Biopolymers from Renewable Resources, Springer, New York, 1998.

2) U.Biermann, W.Friedt, S.Lang, W.Lühs, G.Machmüller, J. O. Metzger, M. Rüsch gen. Klaas, H. J. Schäfer, and M. P. Schneider, Angew. Chem., Int. Ed., 39, 2206 (2000).

3) A. K. Mohanty, M. Misra, and G. Hinrichsen, Macromol. Mater. Eng., 276/277, 1 (2000).

4) M.Biswas and S.S.Ray, Adv. Polym. Sci., 155, 170 (2001).

5) M. Kawasumi, J. Polym. Sci. Part A: Polym. Chem., 42, 819 (2004).

6) A. Usuki, N. Hasegawa, and M. Kato, Adv. Polym. Sci., 179, 135 (2005).

7) H. Uyama, M. Kuwabara, T. Tsujimoto, M. Nakano, A. Usuki, and S. Kobayashi, Chem. Mater., 15, 2492 (2003).

8) H. Uyama, M. Kuwabara, T. Tsujimoto, M. Nakano, A. Usuki, and S. Kobayashi, Macromol. Biosci., 4, 354 (2004).

9）中條 澄, ポリマー系ナノコンポジット, 工業調査会, 2003 年

10) T. Tsujimoto, H. Uyama, and S. Kobayashi, Macromol. Rapid Commun., 24, 711 (2003).

11) H. Uyama, T. Tsujimoto, and S. Kobayashi, Network Polymer, 25, 124 (2004).

12) R. Murugavel, A. Voigt, M. G. Walawalkar, and H. W. Roesky, Chem. Rev., 96, 2205 (1996).

13) http://www.daicel.co.jp/celgreen/

14) M. S. Lindblad, Y.Liu, A.--C. Albertsson, E. Ranucci, and S. Karlsson, Adv. Polym. Sci., 157, 141 (2002).

15) S. Mecking, Angew. Chem., Int. Ed., 43, 1078 (2004).

16) T. Iwata, Macromol. Biosci., 5, 689 (2005). 